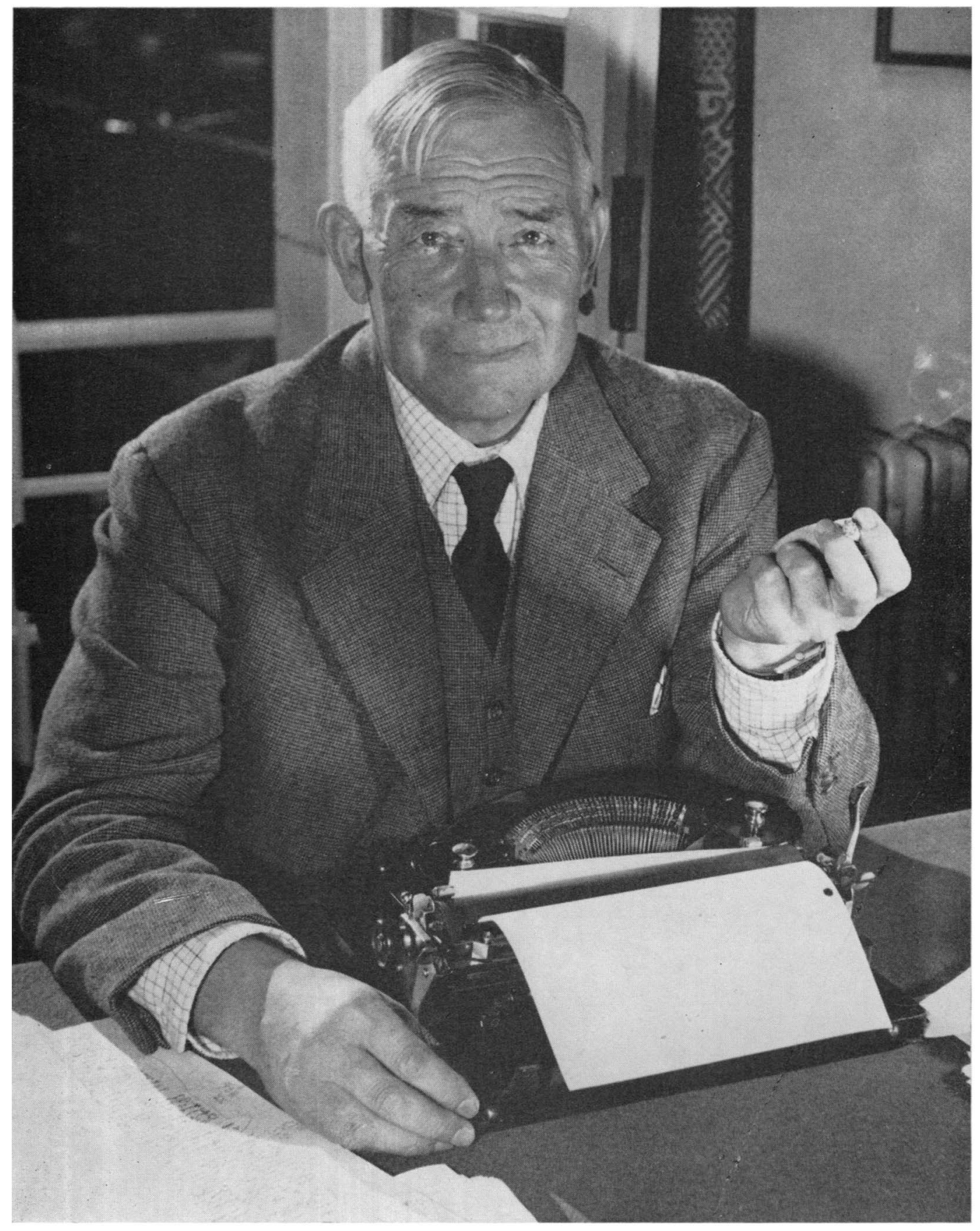

Copyright Oxford Mail and Times 


\section{JOHN PERCY VYVIAN DACRE BALSDON}

I90I-1977

Dacre Balsdon became a member of the Roman Society in 1927 ; he was first elected to the Society's Council in 1934; he became one of its Vice-Presidents in 1954; he was its President from 1968 to 1971 .

By then he was not only a well-known but a recognized and respected scholar (FBA 1967, D.Litt. Oxon. 1968). Yet the paraded air of amused, even cynical detachment; the suave mannerisms of speech and gesture; the occasional outbursts of shocked expostulation: such things may have caused some people to anticipate that, as President, he would be overbearing in the Chair, negligent in administration, or insufficiently attentive to the claims of learning. If so, they were most happily proved wrong on all counts. He made an excellent Chairman, scrupulously fair, who did not even take the opportunity to force through measures he had long been advocating (for example, the 'trimming' of the $\mathscr{Y} R S$ pages began only in 1974 - 'I am glad to have lived to see it', he then observed). He quietly ensured, without undue interference, that the then reconstituted Editorial Committee got off to a good start, and that Britannia got off to an even better one : for it was he who proposed the 'launching party' which was such a notable financial as well as spiritual benefit, and which was the forerunner of the parties now regularly held after lectures. As for the administrative side, he was conscientious to a fault, and he is affectionately remembered by very many in Gordon Square as a President who was always approachable, ready to listen, and ready, if need be, to take endless trouble.

This last tribute would have been no surprise at Exeter College, Oxford, where he was a Fellow from 1927 to 1969 -his old 'undergraduate College'. Nor would the rest have surprised any who had experienced his Chairmanship of the Faculty of Archaeology, History and Letters of the British School at Rome (from 1959 to 1963 ), during which, assisted by his Treasurer, Maurice Lush, he threw all his energies into the School's Library Extension Appeal-and raised thereby some $£ 20,000$, enabling the underground extension of that vital library to be built.

Nevertheless, there remains an element of paradox, appreciated by no one more than the man himself, which he would not expect his Literary Executor to let pass without comment.

'A book about Oxford should avoid being sentimental and smug. This, like all books about Oxford, is both ' (Oxford Life, 1957 ed., p. 17). There, in two sentences, we have the awareness of vulnerability and the outwardly contemptuous snap of the fingers in the world's face. In public, he was often so. In private, he was neither so succinct nor so arrogant. He did not vaunt or conceal the fact that he was a Devon farmer's son (cp. Who's Who, 1976), who had got to Walter De Stapledon's College largely thanks to a lot of hard work on his own part (and he continued to work himself hard thereafter). He was well aware that, in comparison with many contemporary scholars, his career had been undisturbed, his ambience cosy; and that some of the characteristics which made him a good Tutor and a good 'College Man' at Oxford might well detract from his reputation as a scholar, both there and elsewhere. But Balsdon was a man whose heart ruled his head to a great extent, and his heart was very often involved. For example, he served institutions loyally throughout his working life; but he thought of them primarily as collections of persons-past, present and to come. He might grace their buildings with gardens, his own rooms with pictures : it was all done for the people, dead or alive or yet to live, who were thus, in one way or another, committed to his charge.

The same personal involvement characterized his researches into Ancient History and his estimates of ancient persons and Ancient Historians alike. A few examples must here suffice. The brilliant study of Rome and Macedon published in this fournal in I954 was at least in part a response to Holleaux's treatment of Livy. He did not think well of scholars who spoke ill of Flamininus. Caesar evoked his profound admiration, as his fulius Caesar and Rome (1967) showed. In Roman Women (1962), the Elder Julia was accorded the same sort of sympathetic treatment as her grandson, The Emperor Gaius (Caligula) had been given in 1934. Matthias Gelzer was one of his heroes : the long review of his Kleine Schriften in Gnomon I 965 was written mainly with his British undergraduate pupils in mind, who had so much to gain, he thought, from acquaintance with the work of such a historian. By contrast, whenever Jérôme Carcopino published a new book, scholars came to expect a sharp rejoinder from Balsdon's pen very shortly, and it was usually forthcoming.

And so, far from being the serenely remote, even supercilious bystander he at times, in deliberate irony, affected, Balsdon was perhaps too emotionally committed (and, from what he said to me once, I think he knew it) to be an absolutely reliable analyst of historical material, even though his life-long accumulation of such data is, I can testify, prodigiously impressive. (For rather similar reasons, it could be said that he was not a wholly convincing writer of dialogue in his works of fiction.) None the less, he was, as so many of us today are not, a person; and this Society was surely extraordinarily fortunate to have had the services, as President, of such a man at a crucial stage in its history when, by a happy chance, his most firmly rooted, though most carefully concealed, qualities were the very ones of which we stood most urgently in need. 